\title{
Interpretacja niezgodności spawalniczych w złączu T-joint z podkładką podczas badań ultradźwiękowych
}

\author{
Marcin Górecki ${ }^{1}$, Michal Jordan ${ }^{2}$ \\ ${ }^{l}$ Katedra Konstrukcji Budowlanych, Wydziat Budownictwa i Architektury, Politechnika Lubelska, \\ e-mail:m.gorecki@pollub.pl \\ ${ }^{2}$ Przedsiębiorstwo Specjalistyczne DRACO Lesiński Spółka Jawna, e-mail: m.jordan@draco.com.pl
}

Streszczenie: Jedną z najczęściej stosowanych metod oceny poprawności wykonania złączy spawanych jest nieniszcząca metoda wykorzystująca fale ultradźwiękowe. Praktyka pokazuje, że pomimo wymagań stawianych personelowi wykonującemu badania, w wielu przypadkach niezgodności w spoinach czołowych w połączeniach typu T-joint z podkładką stalową są błędnie interpretowane, a w konsekwencji prowadzą do zbędnej i kosztownej naprawy złączy. W pracy zaprezentowano wyniki badań przeprowadzonych na próbkach kontrolnych, w których w rzeczywistości nie występują niezgodności spawalnicze, ale powstające wskazania na ekranie defektoskopu mogą świadczyć o występowaniu niezgodności w postaci wady pozornej.

Słowa kluczowe: niezgodności spawalnicze, wada pozorna, złącze T-joint, spoina czołowa, badania ultradźwiękowe, głowica skośna, transformacja fali, granica ośrodków, obwiednia impulsu.

\section{Wstęp}

Spawalnictwo jest dziedziną, która wymaga przestrzegania surowego reżimu technologicznego. Niezmiernie ważna jest kontrola samego procesu spawania, ale również istotna jest metodologia kontroli produktu końcowego tego procesu. Podczas kontroli jakości wykonanej spoiny przez dugi okres czasu posługiwano się pojęciem „wada złącza spawanego”. Normy dotyczące zarządzania jakością, między innymi norma PN-EN ISO 9000 „Systemy zarządzania jakością. Podstawy i terminologia,, [1], jednoznacznie definiuje pojecia wada. Według tego dokumentu wada to niespełnienie wymagania, czyli niespełnienie potrzeby lub oczekiwania, które zostało ustalone, przyjęte zwyczajowo lub jest obowiązkowe, odnoszące się do zamierzonego lub wyspecyfikowanego użytkownika. Obok pojęcia wady, w wyżej wymienionej normie, pojawiła się definicja niezgodności - to niespełnienie wymagania, czyli niespełnienie potrzeby lub oczekiwania, które zostało ustalone, przyjęte zwyczajowo lub jest obowiązkowe [2]. Podążając za normą [1], do spawalnictwa wprowadzono pojęcie „niezgodności spawalniczej”, zastępując pojęcie „wada złącza spawanego”. Norma [1] zwraca uwagę na różnice występujących między pojęciami „wada” a „niezgodność”. Różnica ta jest ważna, ponieważ posiada konotacje prawne, W szczególności te, które związane są z zagadnieniami odpowiedzialności za wyrób. W rezultacie zaleca się stosowanie terminu „wada” z największą ostrożnością. W ocenie jakości spoin słowo „wada” powinno być stosowane w sposób przemyślany, ponieważ w normie PN-EN ISO 6520-1[N11], klasyfikującej geometryczne niezgodności spawalnicze w metalach, określono ,wadę” jako niedopuszczalną niezgodność spawalniczą [3]. 
Badania spoin mogą odbywać się w sposób niszczący złącze lub w sposób nieniszczący. Złącza wykonywane na obiektach docelowych wymagają jednak badań nieniszczących ze względu na finalną postać wykonywanego wyrobu. W grupie tych badań można wyróżnić następujące typy: badania wizualne (VT), badania penetracyjne (PT), badania magnetyczno-proszkowe (MT), badania radiograficzne (RT), badania ultradźwiękowe (UT), badania prądami wirowymi (ET) i inne niekonwencjonalne metody badań nieniszczących. Dobór metody badań nieniszczących zależny jest od odpowiedzialności konstrukcji (klasy konstrukcji) lub wymogów klienta. W większości przypadków wykonuje się w 100\% badania wizualne, a następnie w zależności od wielu czynników kolejną metodę lub kombinacje metod. Przy wyborze metody należy uwzględnić kilka czynników:

- zastosowany materiał podstawowy w konstrukcji,

- zastosowany materiał dodatkowy,

- zastosowane metody spawania,

- typ / rodzaj złącza,

- wymiary złącza,

- dostępność miejsca kontrolowanego,

- stan obróbki cieplnej materiału podstawowego,

- obowiązujące poziomy jakości wykonania oraz dopuszczenia do eksploatacji,

- spodziewane rodzaje niezgodności spawalniczych.

Biorąc pod uwagę powyższe czynniki, nastawiając się na nieciągłości zorientowane wewnątrz spoiny, najbardziej uniwersalną metodą badań nieniszczących, a jednocześnie dającą wysoki poziom wykrywalności niezgodności spawalniczych jest metoda badań ultradźwiękowych. Metoda ta charakteryzuje się dużą mobilnością, możliwością wykonywania badań $\mathrm{z}$ dostępem z jednej lub obu stron do badanego obiektu, informuje o stanie, w którym znajduje się cała objętość kontrolowanego elementu. Ponadto jest to najlepsza metoda wykrywania wewnętrznych nieciągłości płaskich z określeniem jej położenia i wymiarów i jest stosowana do wykrywania wewnętrznych niezgodności spawalniczych w złączach ze spoinami z pełnym przetopem.

Metoda badań ultradźwiękowych posiada pewne ograniczenia w skali czterostopniowej. Koszt kontroli plasuje się na drugim miejscu, a w szczególności jest to droga metoda w odniesieniu do dużych konstrukcji. Wymaga wysokich kwalifikacji i dużej praktyki od osób wykonujących badanie i wymaga powierzchni kontaktowej pozwalającej na wprowadzenie fali ultradźwiękowej. W przypadku, kiedy stosuje się badania ultradźwiękowe w złączach ze spoinami czołowymi z częściowym przetopem i złączach ze spoinami pachwinowymi, nie przetopiona grań może uniemożliwić przeprowadzenie badań objętościowych w sposób zadowalający.

Nazbyt ostrożne podejście osób uprawnionych do oceny występowania niezgodności spawalniczych w spoinach, nierzadko prowadzi do konieczności wykonywania spawania naprawczego. Uznaje się jednak, że jakość złączy po spawaniu naprawczym jest zwykle niższa niż złączy nienaprawionych, zawierających niezgodności spawalnicze. Jest to spowodowane głównie wprowadzeniem do złącza dodatkowych spawalniczych naprężeń własnych. Normy i przepisy wykonania konstrukcji spawanych ograniczają liczbę napraw tego samego obszaru złącza do jednej naprawy w obszarze grani, a maksymalnie dwóch w obszarze środkowym i licu spoiny [4]. Można spotkać się z przypadkami, kiedy dokonywano napraw w niewłaściwym obszarze złącza lub pozostawieniu w złączu naprawianym niezgodności. 
Jednym z przypadków wykonywania złączy teowych jest spawanie jednostronne czołowe o dużej grubości, z pełnym przetopem z podkładką metalową, wymagających ukosowania na $\mathrm{V}$. Ważne jest odpowiednie podparcie ciekłego metalu jeziorka spawalniczego do czasu aż zakrzepnie [5]. Niestety, badania tego typu złączy również sprawiają sporą ilość problemów. Popularną metodą badania nieniszczącego jest badanie ultradźwiękowe i niejednokrotnie jest błędnie interpretowane. Podczas takiego badania wykazuje się, że niezgodność, a raczej już wada jaka tam występuje to brak przetopu. Na fotografii 1 przedstawiono przykładowy wynik pomiaru UT dla spoiny o grubości $20 \mathrm{~mm}$. Na podstawie raportu wewnętrznego dokonano negatywnej oceny spoiny o długości około $8000,00 \mathrm{~mm}$ wskazując na brak przetopu. Według tego samego raportu wykazano, że na innych sekcjach badanego obiektu, występują spoiny, które otrzymały negatywną ocenę. W kilku przypadkach wskazania występowały poza spoiną, np. przy grubości $15 \mathrm{~mm}$ niezgodności znajdowały się na $18 \mathrm{~mm}$.
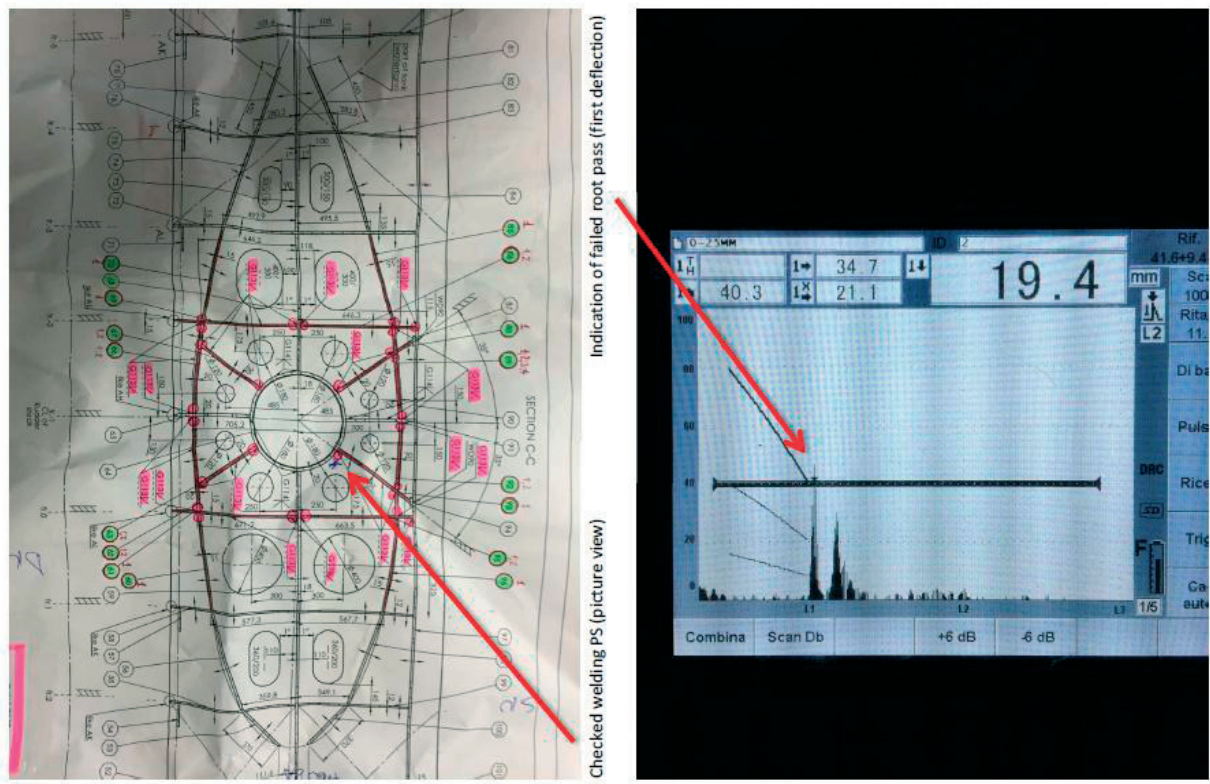

Fot. 1. Fragment raportu, na podstawie którego stwierdzono brak przetopu

Powtórne badania kontrolne nie potwierdziły wcześniej wyprowadzonych wniosków. Raport z powtórnego badania stwierdzał poprawność wykonania złączy. W celu wyjaśnienia niewłaściwej interpretacji wskazania wykonano kilkanaście złączy próbnych w różnych konfiguracjach, które poddano badaniom kontrolnym.

\section{Badania zlączy próbnych}

\subsection{Sposób przygotowania zlączy próbnych}

W przeprowadzonych badaniach wykorzystano 12 próbek złączy typu T-joint z podkładka stalową i jedną próbkę w postaci złącza doczołowego. Blachy elementów próbnych różniły się nie tylko cechami geometrycznymi takimi, jak grubość, ale również sposób przygotowania krawędzi elementów złącznych był różny. Sposób ustawienia elementów 
złącznych względem siebie, czy sposób lokalizacji podkładki także był zmienny w poszczególnych próbkach. Spawanie próbek odbywało się w dwóch pozycjach spawania: podolnej (PA) i pionowej z dołu do góry (PF). Zastosowano dwie metody spawania: spawanie łukowe elektrodą topliwą w osłonie gazu aktywnego (135) i spawanie drutem proszkowym w osłonie gazu aktywnego (136). Na rysunku 1 pokazano schemat przygotowania złączy próbnych a w tabeli 1 zestawiono cechy geometryczne tych złączy.

Każda z próbek posiadała stałą długość równą $300 \mathrm{~mm}$. Blacha dochodząca w złączach teowych miała taką samą grubość równą $15 \mathrm{~mm}$ a sposób ukosowania blachy umożliwiał wykonanie spoiny $1 \frac{1}{2} \mathrm{~V}$. Jedna $\mathrm{z}$ próbek złącza teowego i próbka złącza doczołowego przygotowywane były w obecności pracownika jednostki normalizującej i certyfikującej RINA.
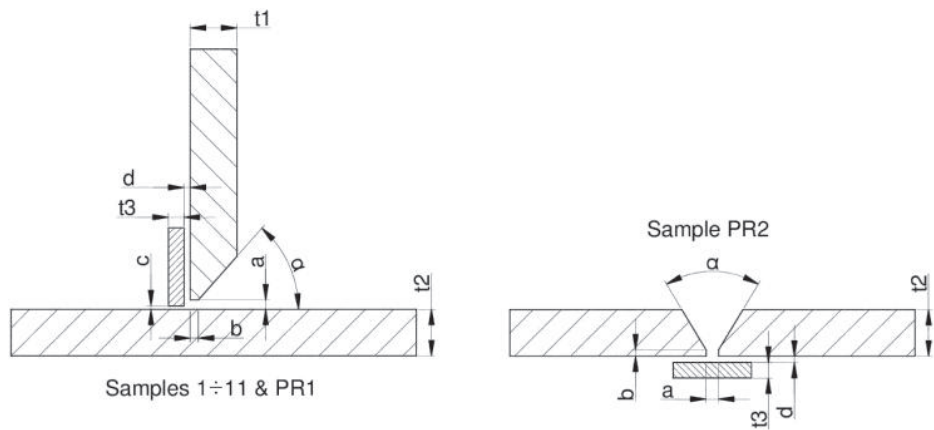

Rys. 1. Schemat złączy próbnych

Tabela 1. Charakterystyka złączy próbnych

\begin{tabular}{|c|c|c|c|c|c|c|c|c|c|c|}
\hline \multirow{2}{*}{$\begin{array}{c}\mathrm{Nr} \\
\text { próbki }\end{array}$} & \multicolumn{3}{|c|}{ Grubość } & \multirow{2}{*}{$\begin{array}{c}\begin{array}{c}\text { Kąt } \\
\text { ukos. }\end{array} \\
\alpha \\
{\left[{ }^{\circ}\right]}\end{array}$} & \multirow{2}{*}{$\begin{array}{c}\text { Odstęp } \\
\begin{array}{c}a \\
{[\mathrm{~mm}]}\end{array}\end{array}$} & \multirow{2}{*}{$\begin{array}{c}\text { Próg } \\
\begin{array}{c}b \\
{[\mathrm{~mm}]}\end{array}\end{array}$} & \multicolumn{2}{|c|}{$\begin{array}{c}\text { Podkladka } \\
\text { stalowa }\end{array}$} & \multirow{2}{*}{$\begin{array}{l}\text { Pozycja } \\
\text { (metoda) }\end{array}$} & \multirow{2}{*}{ Uwagi } \\
\hline & $\begin{array}{c}t_{1} \\
{[\mathrm{~mm}]}\end{array}$ & $\begin{array}{c}t_{2} \\
{[\mathrm{~mm}]}\end{array}$ & $\begin{array}{c}t_{3} \\
{[\mathrm{~mm}]}\end{array}$ & & & & $\begin{array}{c}c \\
{[\mathrm{~mm}]}\end{array}$ & $\begin{array}{c}d \\
{[\mathrm{~mm}]}\end{array}$ & & \\
\hline 1 & 15 & 15 & 5 & $30-35^{\circ}$ & 2 & 0 & 0 & 0 & PA (135) & \\
\hline 2 & 15 & 15 & 5 & $30-35^{\circ}$ & 4 & 0 & 0 & 0 & PA (135) & \\
\hline 3 & 15 & 15 & 5 & $30-35^{\circ}$ & 6 & 0 & 0 & 0 & PA (135) & \\
\hline 4 & 15 & 15 & 5 & $30-35^{\circ}$ & 2 & 2 & 0 & 0 & PA (135) & \\
\hline 5 & 15 & 15 & 5 & $30-35^{\circ}$ & 4 & 2 & 0 & 0 & PA (135) & \\
\hline 6 & 15 & 15 & 5 & $30-35^{\circ}$ & 4 & 0 & 0 & 2 & PA (135) & \\
\hline 7 & 15 & 15 & 5 & $30-35^{\circ}$ & 4 & 0 & 2 & 0 & PA (135) & \\
\hline 8 & 15 & 15 & 5 & $30-35^{\circ}$ & 4 & 0 & 0 & 2 & PF (136) & \\
\hline 9 & 15 & 20 & 5 & $30-35^{\circ}$ & $3-4$ & 0 & 0 & 0 & PF (136) & \\
\hline 10 & 15 & 20 & 5 & $30-35^{\circ}$ & 6 & 0 & 0 & 0 & PF (136) & \\
\hline 11 & 15 & 15 & 5 & $30-35^{\circ}$ & 4 & 0 & 0 & $0-3$ & PF (136) & \\
\hline PR1 & 15 & 15 & 5 & $30-35^{\circ}$ & 6 & 0 & 0 & 0 & PA (135) & Obecność \\
\hline PR2 & - & 15 & 5 & $30-35^{\circ}$ & 6 & 0 & - & 0 & PA (135) & Inspektora RINA \\
\hline
\end{tabular}

\subsection{Metoda pomiaru i aparatura badawcza}

W celu weryfikacji niezgodności spawalniczych i interpretacji wyników zastosowano taką samą metodę pomiaru jak w przypadku wątpliwej konstrukcji czyli metodę badań ultradźwiękowych. Podstawowym urządzeniem pomiarowym był defektoskop Sonatest Masterscan - D70. Używano kilku rodzaju głowic kątowych: MWB70 ${ }^{\circ} \mathrm{MWB}^{\circ}$,

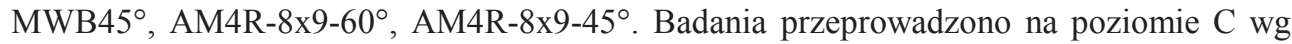


normy PN-EN ISO 17640 [6], przy poziomie akceptacji 2 według tabeli A.1 normy PNEN ISO 11666 [7]. Program badań ultradźwiękowych zakładał wykazanie ewentualnych niezgodności spawalniczych związanych z brakiem przetopu spoiny czołowej na całej długości złącza czyli na odcinku $300 \mathrm{~mm}$.

Wyniki pomiarów zestawiono tabelarycznie (Tab. 2) uwzględniając następujące wielkości: grubość blachy $(t)$, początek wskazania $(X)$, długość wskazania $(L x)$, wysokość punktu ,0” $(Y)$, wskazanie defektoskopu pokazujące teoretyczną głębokość spoiny $(Z)$. Na rysunku 2 zobrazowano sposób wymiarowania wykrytych wskazań.

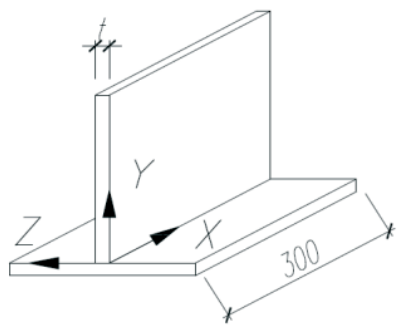

Rys. 2. Sposób wymiarowania wykrytych wskazań

Zastosowana aparatura do badań ultradźwiękowych nie posiada możliwości zapisu przebiegu badania $\mathrm{w}$ związku z tym rejestrowano wszelkiego rodzaju oznaki występujących niezgodności przy użyciu technik fotograficznych tak, jak zostało przedstawione to na zdjęciach (Fot. 2).

a)

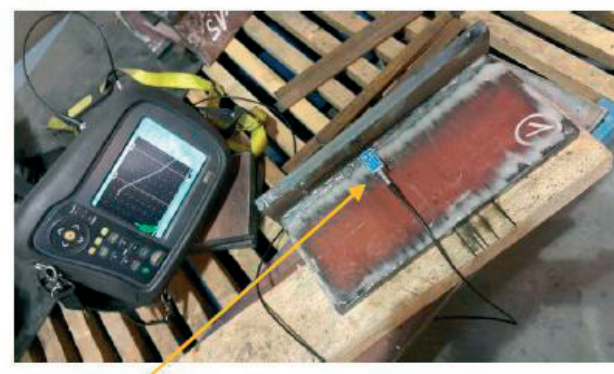

b)

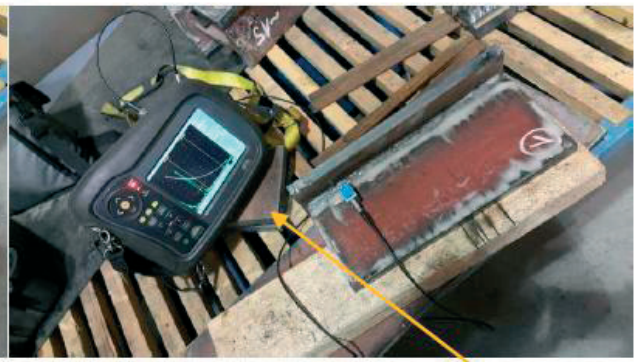

c)

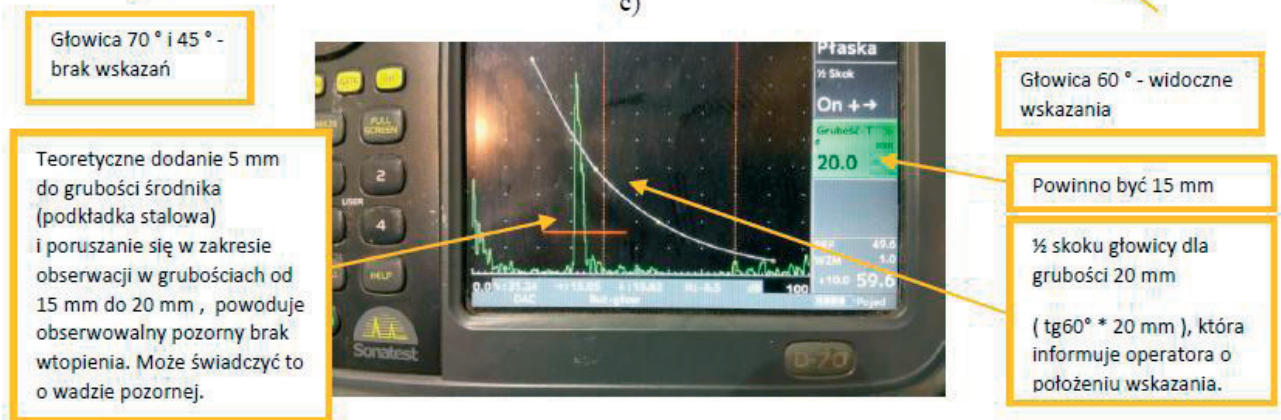

Fot. 2. Próbka nr 1 podczas badań ultradźwiękowych: a) brak wskazania przy użyciu głowic o kącie nachylenia $45^{\circ}$ i $70^{\circ}$, b) wskazanie przy użyciu głowic o kącie nachylenia $60^{\circ}$, c) wskazanie niezgodności spawalniczej poza materiałem rodzimym 
Zastosowane skośne głowice ultradźwiękowe o kącie załamania $70^{\circ}$ i $45^{\circ}$ nie wykazywały występowania niezgodności w żadnej badanej próbce. Głowice o kącie załamania $60^{\circ}$ doprowadziły do ujawnienia ech, obserwowanych na ekranie defektoskopu. Na przykładzie próbki nr 1, teoretycznie, dodając $5 \mathrm{~mm}$ do grubości środnika, czyli grubość zastosowanej podkładki stalowej, i poruszając się w zakresie obserwacji grubości pomiędzy $15 \mathrm{~mm}$ a $20 \mathrm{~mm}$, można zaobserwować występowanie niezgodności spawalniczej interpretowanej niejednokrotnie jako brak wtopienia. Świadczy to jednak o występowaniu wady pozornej, która powstać może z zależności pomiaru obarczonego błędem, wynikającym z rozbieżności wiązki ultradźwiękowej (ocena kąta rozbieżności wiązki w płaszczyźnie padania jest utrudniona z powodu niesymetrycznego usytuowania osi wiązki w polu ultradźwiękowym głowicy) oraz transformacji fali.

Fale, padające pod różnymi kątami na granice wtopu, mogą powodować transformację, czyli zjawisko powstania wiązki fal innego typu niż fala padająca. Towarzyszy to ukośnemu padaniu fali. Po transformacji kąty odbicia i załamania dla fali podłużnej L (transformowała z poprzecznej $\mathrm{T}$ ) są zawsze większe niż dla fali poprzecznej $\mathrm{T}: \gamma \mathrm{L}>\gamma \mathrm{T}$ i $\beta \mathrm{L}>\beta \mathrm{T}$ (zjawisko transformacji fal na granicy ośrodków).

W rozpatrywanym przypadku zgodnie z prawem transformacji i odbicia zachodzi następująca zależność: $\mathrm{T} \rightarrow \mathrm{T}+\mathrm{L}$ (padająca fala $\mathrm{T}$ po odbiciu jest obserwowana jako fala $\mathrm{L}$ po transformacji). Zatem po odbiciu lub załamaniu występują dwa rodzaje fal.

Fala poprzeczna T rozchodzi się w stali z prędkością $3230 \mathrm{~m} / \mathrm{s}$ natomiast fala podłużna $\mathrm{L}$ rozchodzi się z prędkością $5920 \mathrm{~m} / \mathrm{s}$. Dwa razy szybciej poruszająca się fala $\mathrm{T}$ po powrocie do głowicy daje wskazanie pozorne, mogące świadczyć o niepełnym przetopie.

Tabela 2. Zestawienie wyników badań dla próbek $1 \div 11$

\begin{tabular}{|c|c|c|c|c|c|}
\hline \multirow{3}{*}{$\begin{array}{l}\mathrm{Nr} \\
\text { próbki }\end{array}$} & $\begin{array}{c}\text { Początek } \\
\text { wskazania } \\
\end{array}$ & $\begin{array}{c}\text { Długość } \\
\text { wskazania }\end{array}$ & $\begin{array}{l}\text { Położenie } \\
\text { punktu ,0", }\end{array}$ & $\begin{array}{c}\text { Teoretyczna } \\
\text { głębokość spoiny }\end{array}$ & $\begin{array}{c}\text { Grubość } \\
\text { blachy }\end{array}$ \\
\hline & $X$ & $L x$ & $Y$ & $Z$ & $t$ \\
\hline & {$[\mathrm{mm}]$} & {$[\mathrm{mm}]$} & {$[\mathrm{mm}]$} & {$[\mathrm{mm}]$} & {$[\mathrm{mm}]$} \\
\hline 1 & 0 & 300 & 0 & $14 \div 15$ & 15 \\
\hline 2 & 0 & 300 & 0 & $14 \div 15$ & 15 \\
\hline 3 & 0 & 300 & 1 & $12 \div 15$ & 15 \\
\hline 4 & 0 & 300 & 1 & $12 \div 15$ & 15 \\
\hline 5 & 0 & 300 & 0 & $12 \div 15$ & 15 \\
\hline 6 & 0 & 300 & 1 & $12 \div 15$ & 15 \\
\hline 7 & 0 & 300 & 1 & $13 \div 15$ & 15 \\
\hline 8 & 0 & 300 & 1 & $11 \div 15$ & 15 \\
\hline 9 & 0 & 300 & 0 & $18 \div 20$ & 20 \\
\hline 10 & 0 & 300 & 0 & $10 \div 15$ & 15 \\
\hline 11 & 0 & 300 & 0 & $11 \div 15$ & 15 \\
\hline
\end{tabular}

Kolejny etap badań przewidywał usunięcie fragmentu podkładki, dokonanie badań wizualnych, a następnie ultradźwiękowych w celu potwierdzenia pozytywnego wyniku badań. Na odcinku równym połowie długości złącza usunięto podkładki dla próbek $\mathrm{nr} 2,3$, 5. Po usunięciu podkładki, podczas badań wizualnych nie stwierdzono błędnie wykonanej spoiny, w której nie nastąpiłoby całkowite wypełnienie rowka spawalniczego. Wykonano powtórne badanie ultradźwiękowe na odcinku, na którym występowała jeszcze podkładka, i na odcinku bez podkładki. Sposób pomiaru dla próbki nr 3 przedstawiono na Fot. 3.

Urządzeniem OLYMPUS EPOCH 650 przeprowadzono badanie kontrolne dla próbki nr 3. Rezultaty badań były zbieżne $\mathrm{z}$ wynikami otrzymanymi we wcześniejszych badaniach. Kolejnym przyrządem pomiarowym, jaki zastosowano do porównania wyników dla próbki 
nr 3, był defektoskop wykorzystujący technikę Phased Array. Bardziej zaawansowana techni$\mathrm{ka}$, polegająca na elektronicznym sterowaniu wiązką nadawczą głowic liniowych, również wykazywała niezgodności w części próbki, w której występowała podkładka stalowa. Fot. 4 potwierdza zgodność wyników dla wszystkich zastosowanych metod pomiaru wskazań.

a)

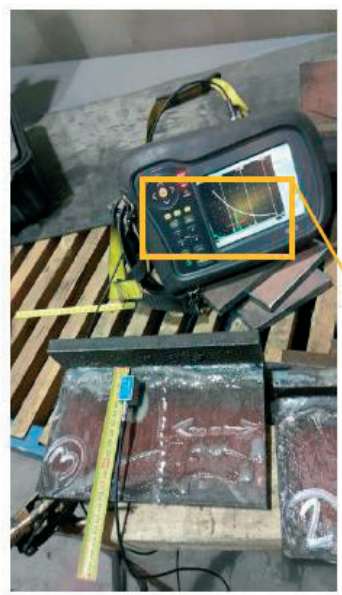

b)

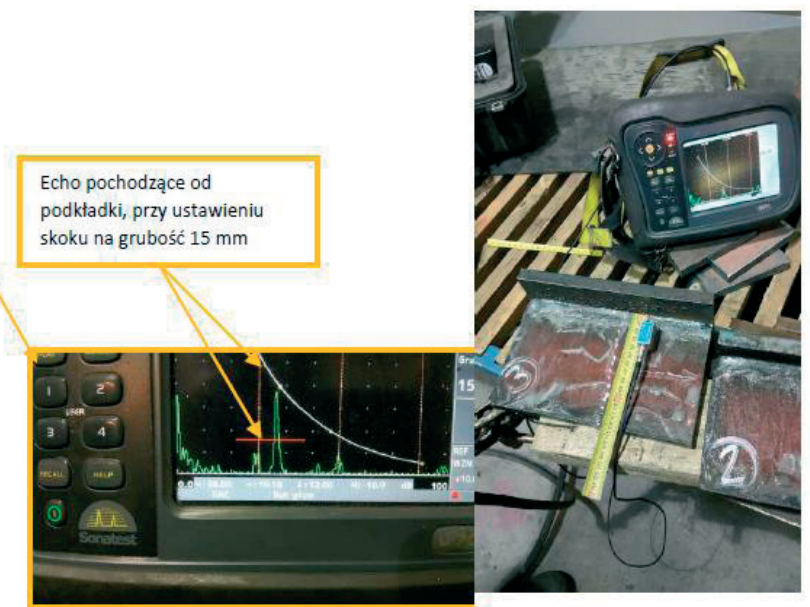

Fot. 3. Próbka nr 3: a) pomiar na odcinku z podkładką, b) pomiar na odcinku z usuniętą podkładką

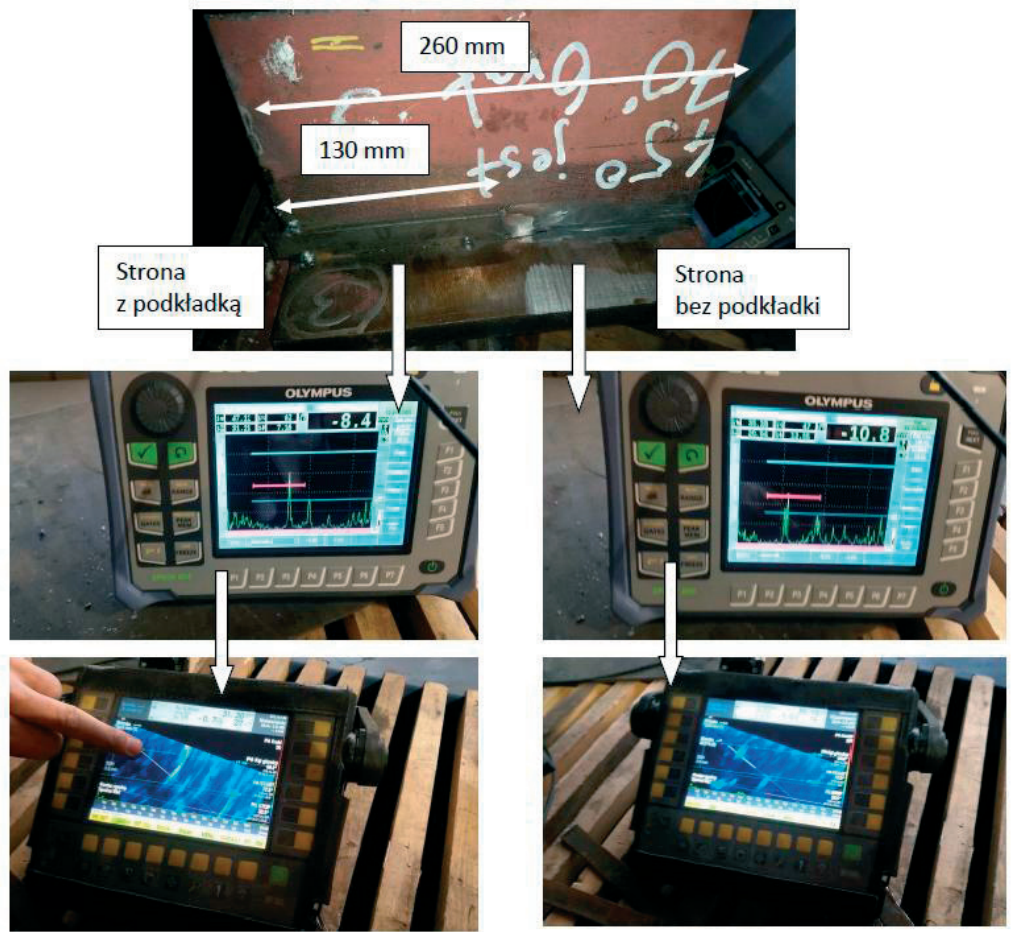

Fot. 4. Wyniki pomiarów dla próbki nr 3 w części z podkładką i w części bez podkładki przy użyciu głowicy skośnej i głowicy wieloprzetwornikowej 
Ostatni etap badań obejmował przecięcie próbek 1, 2, 3, 4, 8, PR1 i wykonanie badań makroskopowych. Badanie przeprowadzono zgodnie z normą PN-EN ISO 17639:2013-12 [8] przy użyciu mikroskopu stereoskopowego Nikon SMZ800N. Dla każdej z próbek przeprowadzono dwa badania. Jedno z badań dotyczyło próbki po stronie gdzie występowała podkładka, drugie badanie dotyczyło części próbki z usuniętą podkładką. W zależności od próbki powiększenie mieściło się w przedziale $1,5 \mathrm{x} \div 1,85 \mathrm{x}$. Na Fot. 5 zaprezentowano obrazy powierzchni zgładu poszczególnych próbek.

a)

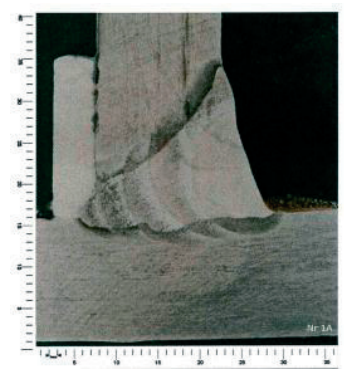

c)

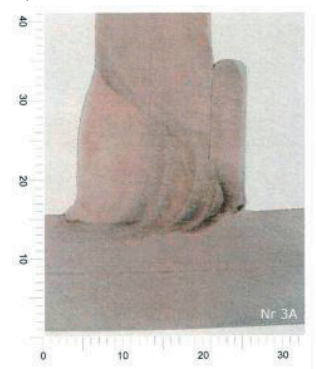

b)

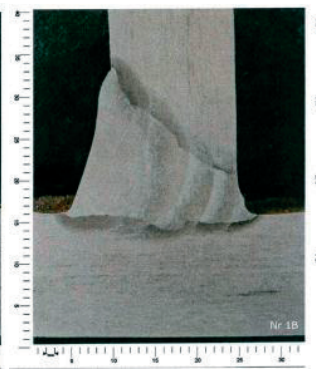

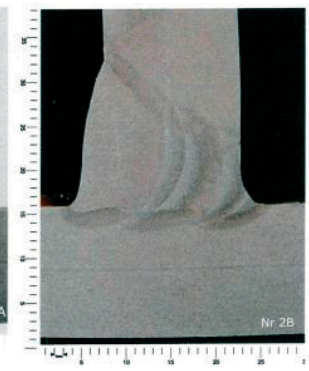

d)
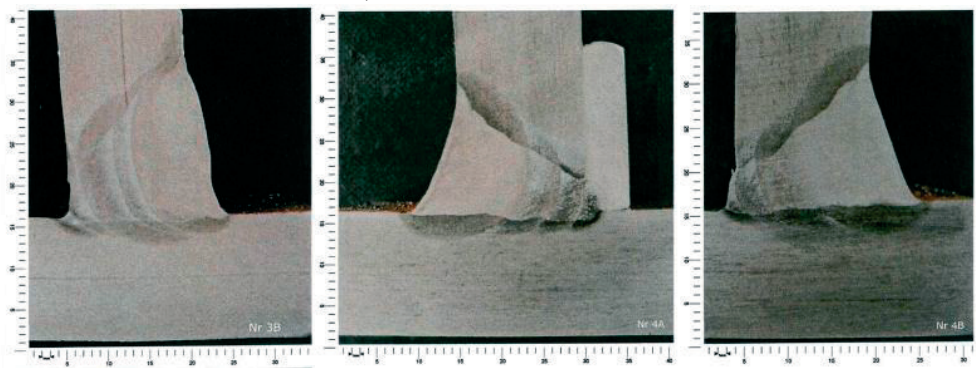

e)
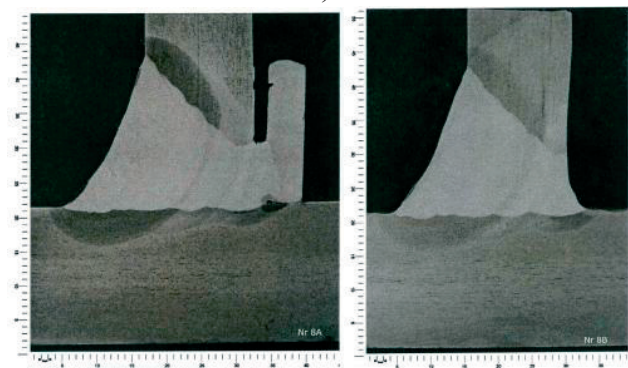

Fot. 5. Powierzchnie zgładu próbek z podkładką i bez podkładki: a) próbka nr 1, b) próbka nr 2, c) próbka nr 3, d) próbka nr 4, e) próbka nr 8

Na podstawie badań makroskopowych nie stwierdzono w żadnym przypadku występowanie jakiejkolwiek niezgodności spawalniczych w materiale, strefie wpływu ciepła (SWC) czy spoinie. Można zaobserwować, że w miejscu występowania podkładki wtopienie obejmuje również obszar podkładki. W drugiej części każdej próbki, po usunięciu podkładki, na przekroju makro widoczne jest prawidłowe wykonanie spoiny z pełnym przetopem. Na Fot. 6 zobrazowano miejsca powstających ech fali ultradźwiękowej odbitej od podkładki spawalniczej. 

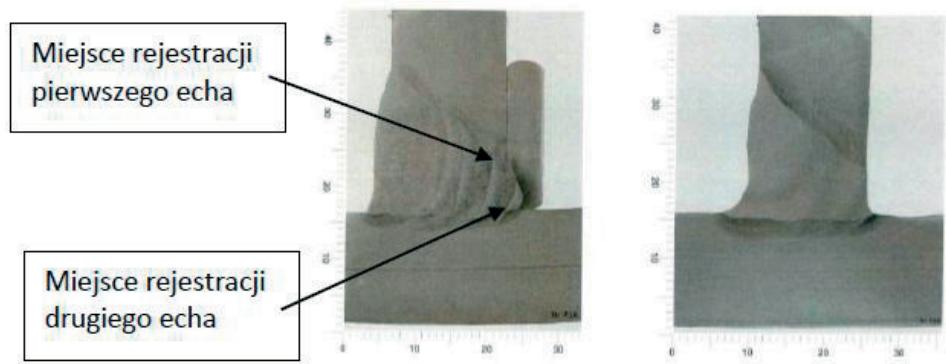

Fot. 6. Rejestrowana niezgodność powstająca w wyniku odbicia fali ultradźwiękowej dla próbki PR1

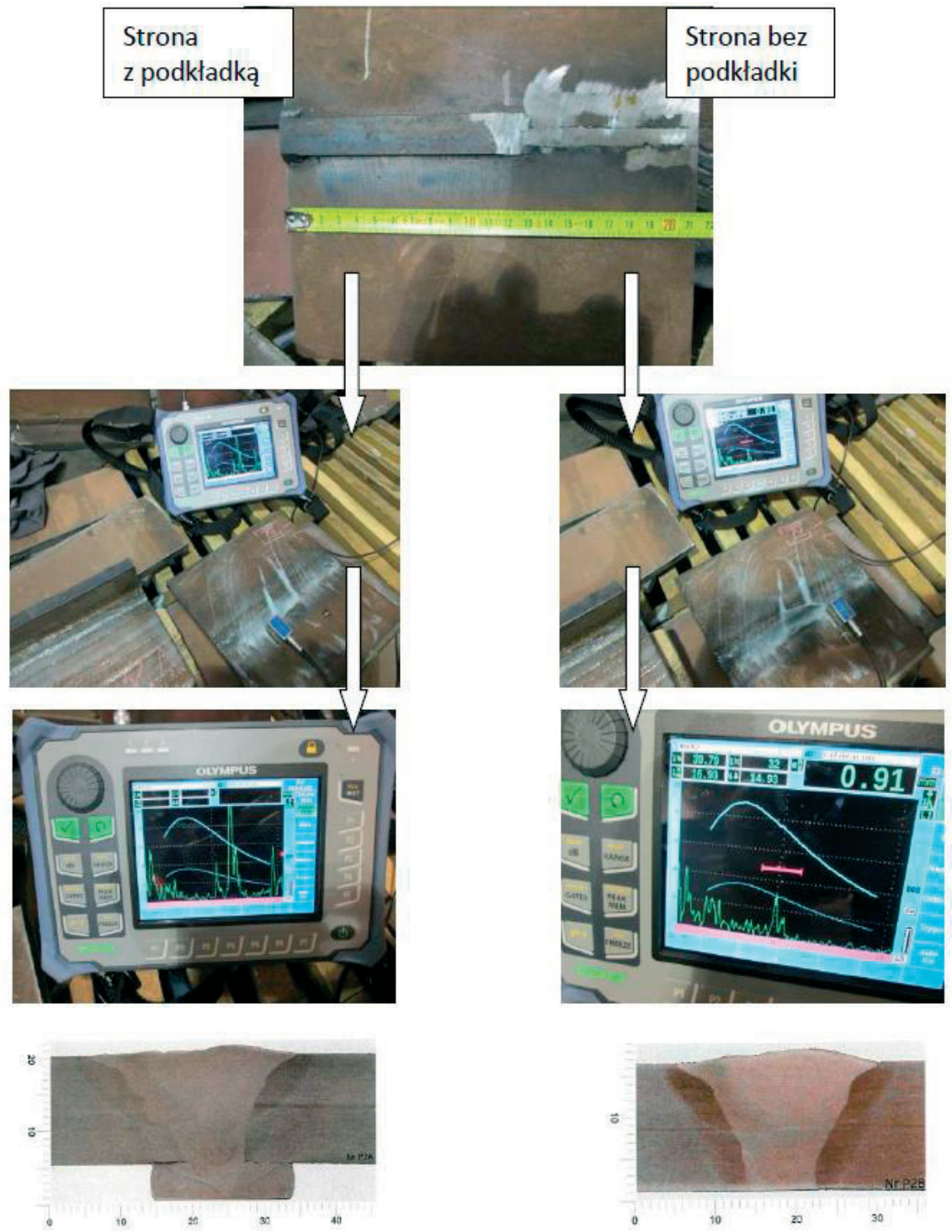

Fot. 7. Próbka ze złączem doczołowym PR2, rejestrowane echa na ekranie defektoskopu i obrazy makro 
W programie badań przewidziano wykonanie dodatkowo złącza doczołowego. Wskazania urządzeń ultradźwiękowych, w obszarze występowania podkładki, świadczyły o występowaniu niezgodności na pograniczu elementów składowych złącza. Po usunięciu podkładki wskazania te już nie występowały. Obrazy makro potwierdziły prawidłowe wykonanie połączenia i brak występowania niezgodności (Fot. 7).

\section{Wnioski końcowe}

W wyniku przeprowadzonych badań na próbnych złączach typu T-joint z podkładką stalową wykazano, że rejestrowane echa na ekranie defektoskopu generowane falą ultradźwiękową za pomocą głowic skośnych w wielu przypadkach nie są niezgodnością spawalniczą interpretowaną jako brak przetopu. Podkładka w złączu typu T-joint powoduje odkształcenie i rant, który odbija sygnał ultradźwiękowy stwarzając pozorne wskazanie. Dodatkowo zachodzi zjawisko odbicia i załamania fali ultradźwiękowej na granicy trzech ośrodków (spoina / materiał / podkładka). Błędne jest traktowanie podkładki jako części spoiny. Zgodnie z nomą PN-EN ISO 15614-1 [9] pkt. 8.3.2.1.e spoinę należy oceniać tylko do grubości nominalnej blachy. Badania makroskopowe potwierdziły prawidłowość wykonanych złączy próbnych kwalifikując je do spełnienia poziomu jakości B według normy PN-EN ISO 5817:2014 [10]. Poziom jakości B odpowiada najwyższym wymaganiom wobec spoin ukończonych.

Badania ultradźwiękowe na złączach T-joint z podkładką mogą prowadzić do błędnej interpretacji wskazań, a w związku z tym do zbędnych prac naprawczych. Szczególną ostrożność należy zachować $\mathrm{w}$ ocenie braku przetopu oraz przy typowaniu operatorów do badań z dużym doświadczeniem zawodowym.

\section{Literatura}

1. PN-EN ISO 9000:2006. Systemy zarządzania jakościa. Podstawy i terminologia.

2. Czuchryj J., Papkala H., Winiowski A. Niezgodności w złączach spajanych. Gliwice 2005.

3. Czuchryj J., Sikora S. Metody i techniki badań nieniszczacych złaczy spawanych. Gliwice 2014.

4. Klimpel A. Kontrola i zapewnienie jakości w spawalnictwie. 1998, Wydawnictwo Politechniki Śląskiej.

5. Klimpel A. Podręcznik spawalnictwa. Tom I. Technologie spawania i cięcia. 2013, Wydawnictwo Politechniki Śląskiej

6. PN-EN ISO 17640:2011. Badania nieniszczace spoin. Badania ultradźwiękowe. Techniki, poziomy badania i ocena.

7. PN-EN ISO 11666:2011. Badania nieniszczace spoin. Badania ultradźwiękowe. Poziomy akceptacji.

8. PN-EN ISO 17639:2013-12. Badania niszczace spawanych złączy metali. Badania makroskopowe i mikroskopowe złaczy spawanych.

9. PN-EN ISO 15614-1. Specyfikacja $i$ kwalifikowanie technologii spawania metali. Badanie technologii spawania. Część 1: Spawanie tukowe i gazowe stali oraz spawanie tukowe niklu i stopów niklu.

10. PN-EN ISO 5817:2014. Spawanie. Złącza spawane ze stali, niklu, tytanu i ich stopów (z wyjatkiem spawanych wiązk). Poziomy jakości wedtug niezgodności spawalniczych.

11. PN-EN ISO 6520-1:2009. Spawanie i procesy pokrewne. Klasyfikacja geometrycznych niezgodności spawalniczych w metalach. Część 1: Spawanie. 


\title{
Interpretation of the welding incompatibility in the $\mathbf{T}$-joint with backing strip during ultrasonic test
}

\author{
Marcin Górecki ${ }^{1}$, Michał Jordan ${ }^{2}$
}

\author{
${ }^{1}$ Katedra Konstrukcji Budowlanych, Wydziat Budownictwa i Architektury, Politechnika Lubelska, \\ e-mail:m.gorecki@pollub.pl \\ ${ }^{2}$ Przedsiębiorstwo Specjalistyczne DRACO Lesiński Spółka Jawna, e-mail: m.jordan@draco.com.pl
}

\begin{abstract}
One of the most common methods for assessing the welded joints is a nondestructive method using ultrasonic waves. Despite the requirements posed to personnel engaged in research, practice shows that in many cases the incompatibilities in the butt welds in T-joint connections with backing strip are misinterpreted and consequently carry out to unnecessary and costly joints repair. The paper presents the results of tests carried out on samples without incompatibilities, for which the indications of defectoscope suggest the occurrence of apparent defect.
\end{abstract}

Keywords: incompatibility welding, apparent defect, T-joint, butt weld, ultrasonic testing, transverse probe, wave transformation, interface, pulse envelope. 
